\title{
The Postwar Compromise and the Future of North American Unionism
}

\section{Charles Smith York University}

David Brody, Labor Embattled: History, Power, Rights (Urbana and Chicago: University of Illinois Press, 2005).

Jonathan Cutler, Labor's Time: Shorter Hours, the UAW and the Struggle for American Unionism (Philadelphia: Temple University Press, 2004).

Rick Fantasia and Kim Voss, Hard Work: Remaking the American Labor Movement (Berkeley: University of California Press, 2004).

Peter S. McInnis, Harnessing Labour Confrontation: Shaping the Postwar Settlement in Canada, 1943-1950 (Toronto: University of Toronto Press, 2002).

Alexander C. Pathy, Waterfront Blues: Labour Strife at the Port of Montréal, 1960-1978 (Toronto: University of Toronto Press, 2004).

By most accounts, the long struggle of working people to entrench the basic right to unionize was realized during the Great Depression and after the Second World War. For North America, the American Wagner Act of 1935 and the PC 1003/Industrial Disputes Investigation Act of 1948 in Canada have often been seen together as the equivalent of organized labour's Magna Carta; for the first time labour rights would be protected by the state, including the basic rights to collectively bargain and to strike. For many of these observers, the era of "free collective bargaining" had arrived. As H. D. Woods argued in the report by the Canadian Task Force into Industrial Relations in 1968, despite some misgivings by employers, it "eventually became apparent that unions and collective bargaining were natural concomitants of a mixed enterprise economy. The state then assumed the task of establishing a framework of rights and responsibilities within which management and organized labour were to conduct their relations." While labour historians have been more reluctant to point to the "natural" evolution of labour relations in the postwar period, among many observers the extension of "industrial democracy" inherent in the postwar compromise continues to be held up as labour's greatest political and economic victory. ${ }^{2}$

Not surprisingly, this interpretation of the postwar compromise has come under significant pressure by left historians and critical legal theorists who have 
$124 \quad$ Smith

long chronicled the structural contradictions of the postwar industrial relations framework. In their thorough review of the labour struggles leading to the introduction of PC 1003, for instance, Judy Fudge and Eric Tucker have argued that the extension of state regulation of collective bargaining in the postwar period represented a double edged sword: on the one hand the state would grant and even protect collective bargaining rights; on the other, unions were forced to accept increased legal regulation of trade union activity, which included complex and uneven certification procedures, the regulation of strike action, and a host of other laws that were administered though provincial legislation, labour relations boards, and the courts. ${ }^{3}$ In examining these political and legal policies Leo Panitch and Donald Swartz have argued that while the postwar framework was designed to create peace between large industrial parties, it in no way represented a dramatic shift in the class relationships inherent within liberal capitalist democracies. Rather, postwar labour relations:

...fashioned a new hegemony for capital in Canadian society. Through formal mechanisms for negotiation and redistribution, consent came to play a visibly dominant role in inter-class relations, while coercion, still crucially present, was in the background. Coercion in capital-labour relations became less ad hoc and arbitrary: as the state's rationalization and institutionalization of workers' freedom of association became more formal, so did coercion. What before had taken the appearance of the charge of the Mounties now increasingly took the form of the rule of law by which unions policed themselves in most instances. ${ }^{4}$

Within these labour relations frameworks, organized labour was forced to play an increasingly critical, albeit contradictory, role: in order to maintain the legitimacy of state regulation, overt political dissent had to be pushed out. In Cold War North America this implied purging Communist officials while simultaneously restricting state-imposed illegal activities, including wildcat and political strikes. ${ }^{5}$ In examining the record of postwar trade union politics after the implementation of the postwar industrial relations framework, it is surprising how successful conservative forces within trade unions were in depoliticizing so much of trade union activity.

This interpretation of the postwar years has gained greater currency with the ascendancy of neo-liberalism across the Western capitalist world. Under neoliberal conditions trade unions in both the private and public sectors have been forced on the defensive as all Western states have abandoned, to varying degrees, the conditions of the postwar framework. In Canada and the United States this abandonment has included a complete retreat in public sector bargaining rights, as governments from all political stripes have increasingly used back-to-work legislation while imposing concessionary contracts on public 
employees. In the private sector, employers have pushed for concessions in real wage levels, pension benefits, and a host of other postwar gains. The new employer assault has been successful in all sectors, most notably in the once union strongholds of the steel, auto, and mining industries. ${ }^{6}$ In all cases, governments and employers utilized the language of neo-liberalism in order to justify their retreat from "free" collective bargaining. As the argument goes, governments must maintain labour peace in order to attract foreign investment and employers must adapt to global economic conditions in order to compete and prosper in the new economy. Inherent within this reasoning is the unsubtle implication that collective bargaining and trade unions are increasingly a hindrance to the functioning of global capitalism.

Given the hegemony of such thinking, it should come as little surprise that labour historians, political scientists, and legal scholars have evinced a renewed interest in the postwar labour framework as they have attempted to explain how neo-liberalism has so successfully subjected even the most militant and progressive of trade unions to declining numbers, stagnant leadership, and successive contractual rollbacks. The contradictions of the postwar labour settlement have risen to the surface within the volumes of work that have emerged in recent years. Indeed, the questions that continue to plague trade union activists regarding the non-unionized and highly gendered and racialized sectors within the economy, the failures of unions to influence the political system to strengthen and deepen freedom of association rights for working people, and the overall decline of union strength in the current climate, all have their roots in the postwar labour relations framework. In their own ways, the works reviewed here maintain that the postwar world of labour relations gives us a more adequate understanding of the economic and political positions of trade union activity today.

It is within this context that we need to examine Peter S. McInnis' book, Harnessing Labour Confrontation: Shaping the Postwar Settlement in Canada. 1943-1950. Unlike many of the histories surrounding the politics of the postwar period, McInnis's study is unique in that he attempts to investigate how state officials, influential business elites, union leaders, political parties, and cultural pressures mobilized to shape the institutionalized structures of the postwar compromise in Canada. In this influential and highly readable history of Canadian labour relations in the 1940s, McInnis has crafted a book that seeks to understand how the Canadian industrial framework emerged in its particular form. Using archival research, government documents, radio transcripts, speeches, and even print media from the pages of Saturday Night and Maclean's, McInnis takes us to a time in which the future direction of the Canadian economy was passionately debated and very much in question. This uncertainty arose for many reasons, including the deepening of the Cold War, the rise of the social democratic left, and, for business elites, the strength of 
126 Smith

organized labour. It was this uncertainty, McInnis argues, that presented working people with a real political and economic space to challenge the power of both the business lobby and Mackenzie King's Liberal state.

Of course, as he painstakingly maps out, the direction of the postwar state was very much in the hands of privileged groups who were not willing to concede the power and advantages that the war years had brought. McInnis outlines in meticulous detail how inter-union rivalry, the Cold War communist chill and the sheer strength of the business lobby worked to shape an industrial framework that limited the collective capacity of trade unions in favour of the mass consumption strategies associated with Canada's "Golden Age" of capitalism in the 1950s and 1960s. In fact, one of the most fascinating details of McInnis' book is the complex strategy employed by capital and the state to defeat union militancy. Traditionally, the state would use open force to break picket lines through the use of the police or, more subtly, by ignoring the employer's use of professional strike breakers. These aggressive practices continued after the war, a fact that McInnis underemphasizes as he suggests that coercion and cooperation commingled in a much more formalized system for suppressing worker dissent. This included the placement of influential union officials into Labour Management Production Committees (LMPCs) effectively co-opting them and blunting their militancy, such as it was. This strategy, McInnis maintains, was successful in introducing a structural form of conservative business unionism into Canada's labour relations system. Under both these political, economic and cultural pressures, McInnis suggests that it became increasingly difficult for trade unions to expand beyond the resource sectors and heavy industry, leaving thousands of workers out of the PC 1003 framework. ${ }^{8}$

Yet, despite the conservative nature of this system, opposition continued to emerge. Opposition came from large employers in many non-unionized areas of the economy, including the resource and retail sectors, which were increasingly lobbying for limitations on trade union freedoms. As several commentators have noted, a central component of this campaign was capital's steadfast refusal to endorse a national labour code. ${ }^{9}$ For McInnis, much of this lobbying was successful because it came not just from industry but increasingly from cultural outlets including newspapers, corporate advertising, popular magazines, and radio. Advertising concentrated on "traditional Canadian values," which were associated with North American capitalism including individual freedom of choice and the protection of free enterprise. For instance, in one particular advertising campaign, the banks suggested that the strength of Canada's rich history was linked to the competitive spirit of capitalism, in which both class and gender equality were natural by-products. ${ }^{10}$ Under this cultural pressure, McInnis maintains that organized labour was gradually pushed into a corner as lobbyists and conservative forces were successful in smearing trade unionism 
with authoritarian labels. It is this analysis which is the real strength of Harnessing Labour Confrontation. McInnis's attempts to marry cultural history with the working class politics of the 1940s are fascinating. Often, labour history is confined to rudimentary categories in which workers are destined to live in a past free from the pages and images of popular culture. In McInnis' book, popular culture is at the forefront as he attempts to craft a story of postwar labour relations in which the politics of labour and capital were hotly debated within the popular media of the time. Yet, as McInnis demonstrates, this culture was wrapped in the narrative of nationalism and the extension and protection of capitalism. Ultimately, the pressure on labour to act responsibly implied that to challenge free-enterprise was to be "un-Canadian."

Within these cultural pressures the spirit of labour-management cooperation, endorsed by the state to maintain union responsibility, implied that freeenterprise was in the driver's seat. It is this examination of the state sponsored cooperation within Labour-Management Production Committees that separates McInnis' work from other studies of the postwar era. Within this examination, McInnis is breaking new ground, as he successfully maps how state regulation actually shaped the floors of production during and after the war. By recognizing the consolidation of labour demands within a quasi-corporatist structure, McInnis contends that we may better understand

\footnotetext{
...how collective-bargaining procedures were successfully inculcated in the workplace, understand the gender assumptions by which trade-union jobs were allocated, and more broadly, learn how LMPCs helped consolidate a new era or routine state intervention under the rubric of cooperation, which in turn, locked union members into a model of behaviour premised upon productivity bargaining and managerial consumption that formed the basis of the "postwar compromise" in Canada. ${ }^{11}$
}

It was in these LMPCs that labour, the state, and employers met to shape the social conditions of work. As such, the LMPCs determined the economic, political, and gendered relations of the postwar world.

Within this analysis, the argument that LMPCs worked to consolidate working class dissent is interesting. Yet, despite this claim, McInnis's examination of labour management committees lacks significant empirical rigour to answer the question he sets out for himself: how did state regulation work to solidify and constrain working class dissent within the institutional structure of the postwar compromise? By his own admission, Canadian labour was never in a sufficiently strong bargaining position to enter into a formal corporatist structure as an equal partner (as was the case in Europe), and, as such, was forced to concede to a disadvantageous and arguably more coercive relationship in which unions were forced to confront the employer not through the picket-line but 
128 Smith

through a state administered LMPC; thus, employers' "management rights" were rarely challenged. Here we see the more simplistic side to McInnis's argument: the seeds of postwar discontent were sown within the LMPC.

There are dual threads running through McInnis' analysis: on the one hand, LMPCs were a vital part of the state's strategy to mute overt trade union struggle. On the other, trade unions themselves were complicit in entering into these agreements as the potential of Keynesian strategies promising high wages and mass consumerism proved too tempting for union leaders to resist. Yet, it is debateable whether the uneven and multiple structures of the postwar compromise fit into such a neat package. Were LMPCs the problem, as McInnis seems to suggest? Or was it simply that the "spirit of cooperation" promoted by Canadian industry, was one experiment among many in which the Canadian state sought to redefine the postwar world so as to promote and protect capitalist enterprise? McInnis argues that the privileged elite within the Canadian Congress of Labour and Trades and Labour Congress were firmly behind the spirit of post-war cooperation, and thus suggests that the LMPCs were symbolic of the broader problems associated with postwar capitalism. What he seems to be suggesting is what Panitch and Swartz, Fudge and Tucker, and Bryan Palmer have already argued: that the working class could not adequately challenge the power of Canadian capital through institutional means alone. Unfortunately, his argument is only on solid ground when he repeats many of these debates, rather then bridging this gap with his own empirical study. In the end, we are left with the artificially neat contradictions of the LMPC structures. While McInnis is clearly on to something here, more research is needed before we can make the conclusions he suggests.

Arguably, the institutional structure of the postwar capitalist world cannot easily be separated from the broader class struggles inherent within the political and economic battles of the 1940s and the 1950s. Central within this struggle was the increasing pressure of political responsibility, which stressed the depoliticization of the trade union movement by aggressive political lobbying from state and business officials. In North America, nowhere was this more present than in the Cold War battles over communism, socialism, capitalism and nationalism on the left. In both Canada and the United States, this pressure brought with it internal conflicts that rivaled, both in style and substance, the grand battles over "Free Enterprise" and "Communism" that engulfed the United States and the Soviet Union in the immediate postwar period. Unlike McInnis' ambitious attempt to link an institutional structure of the postwar compromise onto the limitations of state committees, Jonathan Cutler has written a rich history of a single local within the United Auto Works (UAW) in which all of these questions were openly debated.

In Labor's Time: Shorter Hours, the UAW, and the Struggle for American Unionism, ${ }^{12}$ Jonathan Cutler examines both the internal politics of Local 600, 
the large Ford local located on the Rouge River in Dearborn Michigan, and the Cold War politics gripping the United States between the late 1940s and the early 1960s. In examining Local 600, Cutler is able to accomplish two broad goals: first, he is able tell the riveting tale of the internal politics of a local union which was divided by Communist activists (and smaller factions from the Trotskyist and Socialist Parties) and the more conservative elements of the Association of Catholic Trade Unionists and stalwarts of the UAW bureaucracy, including the contradictory politics of their president, Walter Reuther. Second, and perhaps just as importantly, Cutler demonstrates that the internal politics of Local 600 were really a microcosm of the pressures facing the American left in the 1950 s and 1960s. Immediately following the war, the trade union movement was subjected to the American state's coercive influence in the TaftHartley Act (The Labor-Management Relations Act, 1947), McCarthyism, and the Landrum-Griffin Act, 1959 all of which significantly curtailed the political influence of American trade unionism. As Cutler argues, these pressures forced the UAW (and the American left in general) to abandon broad social goals like the shorter hours movement in order to secure more narrow gains at the collective bargaining table. The narrowness of this vision, he maintains, planted the seeds of American labour's political and economic weakness today.

Aside from small studies, the union local remains a vastly under-researched component of labour history, and for that alone, Cutler's study of Local 600 is a welcome addition to any library. But it would be a mistake to dismiss Cutler's book simply as an isolated history of a large local within the UAW. As Cutler's book brilliantly shows, the UAW, and the Ford Local on the Rouge River in particular, grappled with the most difficult questions facing the American left in the postwar period. Through meticulous research of union newspapers, party newspapers, the Local's elections, and an intimate understanding of postwar American politics, Cutler is able to bring to life the politics of the American left on a grand scale. At the centre of debate in the Local was a question that has gripped left politics since the nineteenth centuryentury: the shorter hours movement. In the nineteenth century, for instance, Marx argued passionately that under capitalism the work week/day would naturally be extended at the expense of working class lives. ${ }^{13}$ In the early twentieth century, left parties in Europe put forward aggressive economic reforms, incorporating the shorter work week into their economic plans. ${ }^{14}$ And in the United States, the left parties and the trade unions fought for the shorter week well into the 1930s when the sit-down strikes of the CIO unions forced the issue on the agenda within heavy industry. Yet, by the end of the Second World War these questions were not at the forefront of postwar planning. Instead, as Cutler shows, the leadership within the unions was keen on playing catch-up, hoping to recoup the losses of the Depression and war years. The two main political parties, the Republicans and the Democrats, publicly declared that any move to shorten the 
$130 \quad$ Smith

work week would prove inflationary and thus came out against doing so.

The issue was not entirely dead, however. Within the UAW, the shorter-hour work week was still an important issue among the left. In particular, as Cutler shows, the shorter work week movement was instrumental in uniting the left across race and class, providing a "progressive response to the challenge of automation and the threat of technological unemployment."'Is In particular, the shorter work week movement centred around the call for full employment through the demand for the 30 hour work week for 40 hours pay (30-40). What is unique about Cutler's book is his attempt to link the shorter hours movement to the broader questions facing the American left in the 1950s and 1960s, including the rise of the civil rights movement and the war on poverty.

At various times, the champions behind the $30-40$ movement within the UAW were the radical left, including the Communists and the Socialists. While this was not true during the war, by the 1950s the Communist and Socialist activists within the Local were at the forefront of a political movement to challenge management control over the work week. Thus, while the left had difficulty taking ownership of the issue ${ }^{16}$ by the $1950 \mathrm{~s}$ it was championing reduced work time. This proved to be a turning point within the Local's internal politics as the anti-communist hysteria of the McCarthy era began to have its impact. Within Local 600, these pressures were at the forefront as the more conservative factions within the Local, led by the Association of Catholic Trade Unionists (ACTists) who were battling the Communists for control of the Local, and thus to end the 30-40 movement. As Cutler demonstrates, however, behind these political battles loomed the overarching powers of the American state as the Taft-Harley reforms and the McCarthy trials aided the ACTists in their political battle in Local 600 .

What is fascinating about Cutler's examination of Local 600 was the transformation of the UAW national President Walter Reuther from radical activist in the 1930s to conservative critic of the 30-40 program in the 1950s and 1960s. Indeed, the story of the fight over Local 600 is really about the attempts of the Reuther administration to purge the radical wing of the Local from the control of the left, including many Communists. But as Cutler demonstrates, Reuther had firmly committed the UAW to the "military Keynesianism" that was so central to America's postwar economic program. Thus, for Reuther the 30-40 program represented not simply a challenge to Ford, but also to the union's responsibility within postwar America. Within this framework what is perhaps most surprising is the strength of the $30-40$ program among the rank-and-file at the Rouge.

Perhaps most interesting in this tale is the story of Carl Stellato who was Reuther's hand picked candidate for President of Local 600. In Stellato, Reuther believed that he had a pliant proxy who could take the 30-40 program off the agenda, thus showing the UAW's commitment to responsible unionism. 
Yet, in Stellato's campaign and subsequent term as President he was forced to take the 30-40 issue seriously, and by the end of the decade became the issue's leading crusader! Of course, Stellato's enthusiasm for the 30-40 program, as Cutler shows, was largely due to his marked political opportunism as the issue refused to die amongst the rank-and-file, many of whom were not affiliated to any political faction within the union. ${ }^{17}$ What became increasingly clear, however, was that the 30-40 issue represented a serious threat to the UAW's public face. As the issue continued to be a centrepiece of Local 600's demands, and thus dominated every convention, Reuther's opposition became increasingly visceral, something even Stellato resisted.

The issue came to the forefront in the early $1950 \mathrm{~s}$ as the House UnAmerican Activities Committee (HUAC) made the unprecedented announcement that it would be taking its show on the road, and that one of its destinations was the motor city. It was announced that the UAW would be subjected to a serious investigation by the McCarthy trials, which proved successful in purging much of Stellato's personal militancy, so much of which was tied to the 30-40 issue. According to Cutler, Reuther seemed quite pleased with the HUAC's investigation. Indeed, in cooperating with the committee, Reuther was successful in linking the 30-40 issue directly to the Communists. ${ }^{18}$ Interestingly, once the committee concluded hearings, Reuther went a step further and established a committee to question the internal operations of Local 600 . In cooperating with McCarthy, Reuther seemed to be incorporating the HUAC tactics. The message became clear: the UAW would not tolerate a radical element in its midst. Reuther was able to take control of the Local, stop the radical presses and ultimately, albeit unevenly, quell internal dissent within the UAW. Perhaps indirectly, Cutler concludes, McCarthy had succeeded. The Communists would be purged. And the $30-40$ program would die with them.

Throughout the rest of the decade Local 600 and the UAW were consumed by consolidating and limiting the power of the Communist Party within the union. In some cases Communists were pushed out, in others, they were strategically replaced or incorporated into the larger UAW bureaucracy. By the 1960s, the UAW emerged as the responsible player it had so long deemed itself to be. For Cutler, however, the price of responsibility was too high. By purging itself of the left, the collective bargaining strategy of the UAW was increasingly narrowed. By the end of the decade, the shorter work week movement was defeated and labour's role in American politics was pushed to the sidelines. The lasting effects of the hours question, Cutler contends, were to leave American labour without a soul, and thus, by the end of the century, labour would be "flat on its back." 19 The message is simple: the death of the shorter hours movement was a contributing, if not defining feature of American labour's long slide into irrelevance.

To be sure, there is little doubt that the story behind American labour's long 
and steady decline is more complex than the shorter hours movement. Cutler's analysis is somewhat guilty of making grand conclusions based on the story of one local within the broader labour movement. Curiously absent from Cutler's analysis, for instance, are labour's ties to the Democratic Party, which put considerable pressure on the unions to adopt a legalistic rather than militant response to the Cold War. Equally important was labour's obsession with eliminating the Taft-Hartley provisions. ${ }^{20}$ By putting its energy into effecting legislation, American labour was convinced it could win concessions from the state that could not be won on the picket line. From responsibility, it was argued, labour could triumph. Of course, the American political landscape proved resistant to these demands. But labour held out, and even today, the TaftHartley provisions are still held up as the cause of American labour's decline. But Cutler's study defies these narrow institutional provisions and gives a much richer analysis of working class history in Cold War America.

The underlying theme in both Cutler's and McInnis' histories is the argument that the postwar framework (however defined) in both Canada and the United States played a significant role in undermining trade union militancy. This structural weakness sowed the seeds for labour's limitation under the global transformation of neo-liberalism. Yet, despite the strength of these arguments, a huge body of literature trumpets the institutional provisions of the postwar settlement. Inherent within much of this literature is an analysis that champions labour-management cooperation and peaceful labour relations as a necessary component of industrial democracy. In two books from this school, Alexander C. Pathy, a management lawyer, and David Brody, a left-leaning institutional historian, argue, in their own ways, that the institutional structures associated with postwar industrial relations could and can act as a unifying force between labour and management.

In Waterfront Blues: Labour Strife at the Port of Montréal, 1960-1978, Alexander C. Pathy outlines in meticulous detail the tumultuous history of labour relations on the Montreal ports. Pathy is obsessed with understanding how the institutional relationship between worker and employer can break down and escalate to violence. For him, the answer lies in the changing nature of production in the maritime ports of the 1960s and 1970s. In Pathy's long and unnecessarily detailed account, the great questions facing organized labour and employers in the 1960s were prevalent on the docks. This pressure was coming largely in the form of technological change, which was a vital part of the managerial revolution sweeping the western world in the 1960s. There is little doubt that Pathy's story deserves to be told, as the Montreal docks provided high drama in the Canadian labour relations field for almost two decades. Within these struggles, the workers' unions were confronted by aggressive employers and a team of labour lawyers, which included a young (and at times overly hostile) Brian Mulroney who won his political spurs in taking on the Montreal 
longshoremen. The longshoremen had long been stalwarts of the International Union movement and were part of the more conservative wing of the AFL-CIO while also being affiliated to the CLC and the Quebec Federation of Labour. The book provides an interesting account of the years when even the traditionally conservative longshoremen were forced to take militant, and often illegal, action in order to preserve and protect their livelihood.

Yet, in outlining this struggle, Pathy unwittingly narrates an empirically rich tale in which the contradictions of the postwar compromise are laid bare. In the ports, collective bargaining was encouraged by the federal government and accepted by the many employers in the industry. However, when management was unable to implement radical changes to the working relationship in the $1960 \mathrm{~s}$ and $1970 \mathrm{~s}$, the state and management showed their willingness to unilaterally end free collective bargaining and resort to delays, legal regulation, and political manipulation to defeat the union. Here we see management and government tactics outlined clearly: endless government studies, commissions, and binding recommendations in which conciliation, mediation, and judicial decisions replaced meaningful collective bargaining in order, it was claimed, to preserve industrial prosperity and peace. Yet, as Pathy demonstrates, because the technological revolution was fundamentally altering the nature of production, labour resisted with increasing anger and violence.

Pathy is unable, it seems, to grasp the nature of this violence. Absent is any discussion of the changes engulfing Quebec in the period, especially the nationalist awakening of the Francophone majority. At times he seems genuinely sympathetic to the union men and their plight, but his book is not interested in asking how the balance of power was structured within the legal regulations implicit in the postwar labour relations framework. Rather, Pathy views labour and management as equal players in a struggle over wages and working conditions. The state, when it was forced to intervene, did so only to create the conditions necessary to end the violence, which was usually blamed on the workers. In Pathy's study, moreover, any notion of state or employer coercion is completely absent.

This should come as little surprise. In one interesting passage, Pathy relates how he and Brian Mulroney were in negotiations with the Royal Bank of Canada for a loan which, he maintained, the company needed to ensure its long term profitability. After recounting how he and Mulroney told the bank that the docks were a permanent staple of long term economic prosperity in Montreal, he goes on to argue in the next paragraph that it "would always be impossible to run the current job-security plan with the current workforce in a financially responsible manner. Unless the workforce was permanently and substantially reduced, the industry would be facing a problem of critical proportions...."22 And with that the employer's strategy was made clear: company profitability had to take precedence over fair and stable wage compensation. In the end, 
Pathy's loyalties, despite his protestations to the contrary, lie firmly with the employer and management's ability to manage the docks with maximum efficiency. The result for Pathy is that the only path to efficiency was in wrestling control of the docks away from the influence of the longshoremen's Unions.

What is interesting about Pathy's study is the extra-parliamentary role that the government assumed to solve the labour strife in Montreal. While seemingly committed to collective bargaining, the Pearson and Trudeau administrations were more than willing to use back-to-work legislation to stop legal strikes. Indeed, as Pathy states in chapter eleven, "The Force of the Law," the union was legislated back to work by the Trudeau government in order to impose a judicially mandated settlement. Perhaps not surprisingly, the union and its leadership reacted with increasing hostility. As we see, by the end of the $1970 \mathrm{~s}$, control of the docks fell overwhelmingly to the companies, who were now free to radically alter the working relationship without the threat of long and violent strikes. Ironically, while Pathy tells this story to justify the actions of the labour lawyers, the company and the state, his book unwittingly shows that the postwar labour framework was less about industrial democracy and free association, and more intended to establish the legal conditions for employer control over the workplace. When unions challenged that notion (or simply reacted to it) the weight of the state was brought to bear on the offending union for challenging the power of the employer. What is perhaps most surprising in Pathy's tale was how long the union sustained its militancy in the face of this official hostility.

Historian David Brody adopts a similar, albeit more sympathetic, analysis in his book, Labor Embattled: History, Power, Rights. ${ }^{23}$ In this work, Brody seeks to understand how the institutions of the American labour framework were unilaterally abandoned by successive government deregulation, antilabour legislation, and overt hostility from both political parties. For Brody, the great Wagner reforms of the 1930s were indeed labour's Magna Carta. The question is how has the state drifted so far from these commitments?

In many ways, Brody is attempting to examine the state of North American labour today. Using American labour history as his tool, he is attempting to understand how institutional structures worked to shape American labour's long decline. To be sure, Brody is a labour historian who is unapologetically sympathetic to organized labour's plight. In this book, Brody seeks to understand how the labour historian can help to interpret the past in order to help explain the impasse of the AFL-CIO today. In chapter two, "The Labour Movement in Historical Perspective," for instance, Brody examines the nature of collective bargaining and state regulation in the United States. Without institutional protection from the state, Brody contends, collective bargaining did not solve the problems of the American worker. There is nothing really controversial here. Clearly, what distinguished North American labour from 
many of its European counterparts was its over-reliance on the state for the preservation and protection of freedom of association.

As a labour historian, Brody is overly concerned with justifying his role in explaining the current state of American labour law. In championing the "old" labour history over the "new" one, Brody maintains that the Wagner Act needs to be understood within the debate surrounding workers' rights. ${ }^{24}$ If rights of association were considered akin to civil rights, he argues, than the American state could not ignore them for long. ${ }^{25}$ The rest of the book is consumed with exploring the institutional history of American labour unions, focusing overwhelmingly on the transformative influences of the law, the positive effects of the Wagner era and the disappointment with the Taft-Hartley provisions in the late $1940 \mathrm{~s}$. Ultimately, the independent variable in Brody's analysis is labour law. If the regressive tendencies of Taft-Hartley could be eliminated, if the sprit of the Wagner period could be revised, and if the unions could align themselves behind this political project, then the long historical decline of American labour could be reversed.

Brody's obsession with labour law reform is grounded in a real problem for American labour. Yet, even at its best, labour law cannot be understood independently of the political economy in which it is grounded. From this perspective, one cannot understand the Wagner reforms of the 1930s without arguing, as many have, that it was designed as much to preserve and protect American capitalism as it was to extend rights to trade unions. ${ }^{26}$ But such analysis is curiously absent in Brody's book. The silence on these questions reflects two weaknesses of this study. First, the book does not read well. It is really a collection of essays that cover a broad and somewhat incoherent spectrum, including historical polemics, speeches, and some conference papers, which vary in quality and in the depth of their research. Indeed, it is curious that Brody chooses to include chapter six at all given that it is only a series of book reviews, which offers little to his overall argument.

Second, and perhaps more profoundly, it is important to highlight that Brody's overemphasis on the transformative potential of labour law borders on the naive. Labour law cannot transform the politics of the state independently of massive working class organizing. In the United States, this would include a political project that sought as much to change the internal functioning of labour unions as it would have to address the structured divisions between race, gender, and class within the country. In Brody's work, the complex and often contradictory relationships inherent within the capitalist economy are rarely seen. Indeed, in many cases, the economy is not even discussed at all. For much of Brody's work, the politics of trade unions, political parties, employers, and the state itself exist independently of political economy. This is a bizarre omission as it is within the American state that the limits of postwar Keynesianism were first apparent and where today, the new-employer offensives associated with neo-liberalism have their strongest footing. 
By comparison, the new book by Rick Fantasia and Kim Voss attempts to address the multiple political and economic questions affecting American labour today. In Hard Work: Remaking the American Labor Movement, ${ }^{27}$ Fantasia and Voss outline in meticulous detail the history of American labour in an attempt to explain its weakness today. Like many of the best works of political economy and economic history, Fantasia and Voss offer an account of the American working class' encounter with neo-liberalism that is both accessible and detailed. Through this book we see that American workers are divided by race, gender, and occupation which, they maintain, has not been accidental. Rather, the current divisions of the working class are a deliberate byproduct of powerful social forces associated with the transition to neo-liberalism. In the United States, neo-liberalism has overemphasized the characteristics of individualism, deregulation, decentralization, and privatization of the labour market. ${ }^{28}$ At the centre of this analysis is that the American working class is increasingly forced to compete in a labour market forcefully separated from fellow workers, which obstructs collective responses to economic realities. The effectiveness of neo-liberalism, Fantasia and Voss maintain, rests in its successful promotion of the myth that only individuals can succeed in the United States. Yet, as they show, the American labour market is increasingly devoid of "good" jobs. The majority of jobs today offer low pay, long hours of work, poor working conditions, and little to no benefits.

Within the field of collective bargaining, Fantasia and Voss could not be clearer on the structural weaknesses of the Wagner area: "the system," they argue, "overwhelmingly favors the employer." ${ }^{29}$ This has left employers in an extremely beneficial position vis-à-vis their employees, as the legislative terrain has allowed employer offensives to drag potential union organizers through the legislative regimes of the National Labor Relations Board and the courts. On top of this, the American state's open endorsement of free trade and mobility rights for American capital has left American workers very much on the defensive. In a globalized world, pressures increasingly force workers to rely on the benevolence of employers, which is rarely forthcoming. On top of global pressures, Fantasia and Voss maintain that the Wagner provisions must be understood as being a thinly veiled attempt to protect and promote American capitalism in the 1930s. The reasons behind the weaknesses of the Wagner model are varied, but the authors maintain that the highly decentralized and privatized system of collective bargaining has weakened the effectiveness of trade unions as they have been unable to break outside of the main industries unionized in the great CIO waves of the 1930s. This has left the benefits of unionization unattainable for thousands of American workers, especially those who were excluded from the Wagner model, such as youths, women, and workers of colour.

Despite these tensions, Fantasia and Voss are not prepared to abandon the American trade union movement. While admitting that it has, since the time of 
Samuel Gompers, been prone to increasingly narrow forms of "business unionism," they maintain that any transformative project in the United States must come from the organized working class. In this regard, the primary goal of the American trade union movement has to be in organizing. Under the conditions of neo-liberalism, however, this cannot be done under the auspices of business unionism, which often only sees new members as contributing to the bottom line. Rather, Fantasia and Voss see the future of the American trade union movement within "social movement unionism" (SMU). For the authors, SMU must focus on building the potential of the working class to see work in political terms. Trade union organizing, they maintain, must incorporate a broad political project which focuses on class organizing. Within the framework of SMU, Fantasia and Voss see hope in recent campaigns launched by the SEIU, UNITE HERE, and CWA which were the unions behind initiatives such as the "Justice for Janitors" campaign. In these campaigns, the unions used unique and often imaginative organizing tactics to organize immigrant janitors (mostly women) in Los Angeles. ${ }^{30}$

Hard Work is an exceptionally well-written book that leaves readers hopeful for the future of North American labour. While much of the book was written before the New Unity Partnership split in the AFL-CIO, the message that Fantasia and Voss have been pushing has been at the centre of Andy Stern and the SEIU's critique of John Sweeny's failed leadership at the head of the AFLCIO. The NUP, which formally split from the AFL-CIO in July 2005 is too new a creation to make any real conclusions about the drift towards "social movement unionism" within American labour. What is clear, however, is that the status quo is no longer acceptable for large segments of the organized working class. As Fantasia and Voss' book outlines, there is hope in this uncertainty. The strength of this book is their unflinching critique of neo-liberalism combined with their unbridled optimism for the collective strength of the American working class.

Within much of the work presented here, there has been a consistent theme questioning the future potential of North American labour. Much of this criticism has revolved around organized labour's role in the "new" liberal economy. In their own way, each of these books attempts to address labour's political weakness today. For these commentators, the future of organized labour is rooted in the past. As each book tells us (deliberately or otherwise), the postwar framework in which the capitalist state was forced to protect and promote workers' freedom of association was always based on a loose economic and political coalition. When those economic realities began to change, the postwar framework also began to break down. The future of the organized, working class, if these works tell us anything, will be in how organized labour builds on the victories of the postwar period in order to challenge neo-liberalism today. 
Notes

1. Task Force on Canadian Industrial Relations, The Report of the Task Force on Labour Relations (The Woods Committee) (Ottawa: Privy Council Office, 1968), 13.

2. The literature on this is vast, but as one example, see Laurel Sefton MacDowell, "The Formation of the Canadian Industrial Relations System During World War Two," Labour/Le Travail 3, (1978): 175-196.

3. Judy Fudge and Eric Tucker, Labour Before the Law: The Regulation of Worker's Collective Action in Canada, 1900-1948 (Toronto: Oxford University Press, 2001).

4. Leo Panitch and Donald Swartz, From Consent to Coercion: The Assault on Trade Union Freedoms (Toronto: Garamond, 2003), 14-15.

5. For a thorough review of the Communist purges in Canada see Irving Abella, Nationalism, Communism, and Canadian Labour (Toronto: University of Toronto Press, 1973). More generally, see Bryan Palmer, Working Class Experience, Rethinking the History of Canadian Labour 1800-1991 (Toronto: McClelland and Stewart, 1992), especially chapter six.

6. According to survey data in 2004 union density in Canada stood at 31 percent. See Statistics Canada, The Labour Force Survey (Workplace Information Directorate Human Resource Development Canada). In the United States, unions have fared far worse, as the national density rate has fallen to thirteen percent, and only nine percent in the private sector. See US Department of Labor, Bureau of Labor Statistics (LRA online). 7. Peter S. McInnis, Harnessing Labour Confrontation: Shaping the Postwar Settlement in Canada, 1943-1950 (Toronto: University of Toronto Press, 2002).

8. See the criticisms in Cy Gonick, Paul Phillips, and Jesse Vorst, eds., Labour Gains, Labour Pains: 50 Years of PC 1003 (Winnipeg: Society for Socialist Studies/Fernwood, 1995).

9. See H.C. Pentland's critique for the Woods Commission, "A Study of the Changing Social, Economic, and Political Background of the Canadian System of Industrial Relations," Report on the Task Force on Labour Relations (The Woods Commission) No. 1 (Ottawa: Privy Council Office, 1968).

10. McInnis, Harnessing Labour Confrontation, 72.

11. Ibid., 114.

12. Jonathan Cutler, Labor's Time: Shorter Hours, the UAW and the Struggle for American Unionism (Philadelphia: Temple University Press, 2004).

13. Karl Marx, Capital: A Critique of Political Economy (New York: International Publishers, 1967), 252-3. Here Marx argued: "The capitalist mode of production ... produces thus, with the extension of the working-day, not only the deterioration of human labour-power by robbing it of its, moral and physical, conditions of development and function. It produces also the premature exhaustion and death of this labour-power itself. It extends the labourer's time of production during a given period by shortening his actual lifetime."

14. Donald Sasson, 100 Years of Socialism (New York: New York Press, 1996), 60-83.

15. Cutler, Labor's Time, 6.

16. After all, in their support of the Soviet Union, it was the Communist Party who had advocated speed up and a no-strike pledge during the war.

17. Cutler, Labor's Time, 53-65. 
18. Ibid., 73-77.

19. Ibid., 181.

20. Kim Moody, An Injury to All: The Decline of American Unionism (London: Verso, 1988), 133-39.

21. Alexander C. Pathy, Waterfront Blues: Labour Strife at the Port of Montréal, 19601978 (Toronto: University of Toronto Press, 2004).

22. Pathy, Waterfront Blues, 214-15.

23. David Brody, Labor Embattled: History, Power, Rights (Urbana and Chicago: University of Illinois Press, 2005).

24. I am unclear on Brody's argument regarding the Old and New labour history. I can only assume that he is referring to the distinction between older institutional historians who focus on the history of trade union organizing, collective bargaining, and state responses. By contrast, the "new" working class history, I imagine, is meant to be that championed by E. P. Thompson and his students, who focus on the rise of working class consciousness, examining how economic, political and cultural pressures gave rise to class struggle. Brody never clarifies his terms.

25. Brody, Labor Embattled, 24.

26. See for instance, Robert H. Zieger and Gilbert J. Gall, American Workers, American Unions: The Twentieth Century (Baltimore: Johns Hopkins University Press, 2002), 29. 27. Rick Fantasia and Kim Voss, Hard Work: Remaking the American Labor Movement (Berkeley: University of California Press, 2004)

28. Fantasia and Voss, Hard Work, 9.

29. Ibid., 19.

30. On this campaign see Preston Rudy, "Justice for Janitors,' not 'Compensation for Custodians': The Political Context and Organizing in San Jose and Sacramento," in Ruth Milkman and Kim Voss, eds., Rebuilding Labor: Organizing and Organizers in the New Union Movement (Ithaca: Cornell University Press, 2004), 149. 